\title{
The Use of Cereal Components in the Preparation of Ice Milk
}

\author{
Fatma Salama, Mohamed Azzam and Mohamed Saad \\ Dairy Sci. Dept., Fac. Agric., Cairo Univ., Giza, Egypt
}

\begin{abstract}
The purpose of this study was to investigate preparation of ice milk mixes by substituting oat milk and oatmeal or barley milk and milled barley instead of buffalo skim milk (BSM) and skim milk powder (SMP) at ratios $0: 100\left(C_{0}\right), 25: 75\left(O C_{25} \& B C_{25}\right), 50: 50\left(O C_{50} \& B C_{50}\right), 75: 25\left(O C_{75} \& B C_{75}\right)$ and $100: 0\left(O_{100}\right.$ \& $\left.B_{100}\right)$ and substituting their blend instead of BSM and SMP at ratio $75: 25$ (OBC $\left.C_{75}\right)$ and evaluation of frozen products physically, sensually, economically and nutritionally. The ice milk made from 100\% BSM and SMP served as the control $\left(C_{0}\right)$. The results showed that replacement of non fat milk solids $(M S N F)$ with grain oat and barley components increased $\mathrm{pH}$ and viscosity values and decreased the specific gravity (Sp.gr), weight per gallon (Wt/gal) and whipping ability of ice milk mixes. Ice milk mixes made from 100\% grain oat and barley components were excluded from the ice milk processing because of their very high viscosity and very low whipping ability. Incorporation of oat's or barley's components into ice milk mixes negatively affected Sp.gr, $W t / g a l$, overrun values and meltdown rate of the resultant ice milks. Results of sensory evaluation showed that most acceptable ice milks compared to untreated ice milk $\left(C_{0}\right)$ they order $B C_{25^{-}}, O C_{25^{-}}, B C_{50^{-}}, O B C_{75^{-}}$and $O C_{50^{-}}$ice milk. Economically, $B C_{25^{-}}$ice milk was the least expensive, followed by $B C_{50^{-}}$and $O C_{25^{-}}$then $O B C_{75^{-}}$ ice milk. The nutritional analysis of ice milks more palatable sensually and economically $\left(B C_{25^{-}}, B C_{50^{-}}, O C_{25^{-}}\right.$ and $\mathrm{OBC}_{75^{-}}$ice milk) indicated that calories, protein, ash, carbohydrate and dietary fibers were found to be good amount in comparison to $C_{0}$. Thus, these ice milks would be highly nutritious and not expensive.
\end{abstract}

Key words: cereal, oat, barley, ice milk, replacement, nutritional analysis.

\section{Introduction}

Nowadays dairy factories are a trend towards increased production of dairy products low in their fat content and rich in nutraceutical and functional properties. Consumers are interested in eating these products that must be acceptable 'taste and appearance' and cheap. Among of these products, many kinds of new regular and low fat ice cream or known as ice milk available in the markets now. Substitution of functional food ingredients with health benefits instead of traditional ingredients in ice cream formulations without altering taste, mouthfeel, or other sensory properties was goal of various studies reported in the literature (Bisla et al., 2012, Karaman and Kayacier 2012, Wangcharoen 2012, Sun-waterhous et al., 2013, Ahanian et al., 2014 and Umelo et al., 2014). Oat (Avena sativa) and barley (Hordeum volgare L.) are under-utilized grains in human nutrition, yet they are good sources of dietary fiber, especially $\beta$-glucan, essential amino-acids, unsaturated fatty acids, vitamins, minerals and antioxidants (Huttner and Arendt 2010). Grain oat and barley products are several such as oat milk and barley milk. Whether is similar to cow milk in its gross chemical composition addition to their iron, zinc and dietary fiber contents (Hurrell et al., 2000). Also, they are similar to cow milk in its fluidity but they have the higher viscosity and starchy taste (Ali 2012). Oat's and barley's milk are cheaper than cow's milk as protein sources with high nutritional value. Consequently, they can be used as a suitable healthy alternative for cow's milk in manufacture of like dairy products (Newman and Newman 2006, Queenan et al., 2007, Walsh et al., 2010 and Ali 2012). The purpose of this study was to substituting oat milk and oatmeal or barley milk and milled barley or their blend instead of buffalo skim milk and skim milk powder in manufacture of like ice milk and evaluation of frozen products physically, sensually, economically and nutritionally.

\subsection{Ingredients}

\section{Materials And Methods}

Fresh raw buffalo's milk was obtained from the herd of the Faculty of Agriculture Cairo University, Egypt and fresh skim milk (9.53\% TS, 0.1\% Fat, 3.7\% Protein, 0.73\% Ash, 5\% Lactose, Sp.gr 1.0391) and cream $(48.48 \%$ TS, $45 \%$ Fat, $1.53 \%$ Protein, $0.12 \%$ Ash, $1.83 \%$ Lactose) were obtained by separating of fresh buffalo's milk using cream separator (made in Egypt). Oat's (Avena sativa) and hull less barley's (Hordeum vulgare - Giza 129) grain were obtained from Agriculture Research Center, Giza, Egypt. Oat milk (9.49\% TS, $0.018 \%$ Fat, $1.16 \%$ Protein, $0.36 \%$ Ash, $7.95 \%$ Carbohydrates, Sp.gr 1.019) and barley milk (9.4\% TS \& $0.01 \%$ Fat, $1.15 \%$ Protein, $0.54 \%$ Ash, $7.85 \%$ Carbohydrates, Sp.gr 1.022) were prepared according to steps were described by Ali (2012). White oat flakes (91\% TS, 8.4\% Fat) made in UK was purchased from the local market. Oat flakes and barley grains were milled (using standard electric grinder, Moulinex ${ }^{\circledR}$, France) and sieved by stainless steel sieves (60 mesh) to obtainment oat's and barley's powder (91\% TS, 7\% Fat, $12.1 \%$ Protein, 2.6\% Ash, 69.3\% Carbohydrates and 92\%TS, 1.22\% Fat, 8.9\% Protein, 2.56\% Ash, 79.32\% 
Carbohydrates respectively). Low heat skimmed milk powder (96\% TS, 1.25\% Fat, 34.5\% Protein, 8.25\% Ash, $52 \%$ Lactose) made in USA, cane sugar (sucrose) and raw vanilla were purchased from the local market. Stabilizer (Lygomme FM 5700) was obtained from Cargil, Germany.

\subsection{Manufacture of ice milks}

According to the Egyptian standards of ice milk (2005), three ice milk mixes [buffalo skim milk/skim milk powder- ice milk mix as control $\left(\mathrm{C}_{0}\right)$, oat milk/oatmeal- ice milk mix $\left(\mathrm{O}_{100}\right)$ and barley milk/milled barleyice milk mix $\left(\mathrm{B}_{100}\right)$ ] were standardized to contain $4 \%$ fat, $12 \%$ MSNF, sugar $13.1 \%$ and $0.3 \%$ stabilizer (Table 1). The liquid ingredients were mixed together in a mixing vessel and heated to $40^{\circ} \mathrm{C}$ in a water bath. The dry ingredients except sugar and stabilizer were added slowly to the liquid mix with gentle stirring. The obtained mixture was blended with the sugar and stabilizer in a mixer (electric mixer, Moulinex ${ }^{\circledR}$, France) at $55^{\circ} \mathrm{C}$ for 2 min. In addition to the three previous basic mixes, six ice milk mixes were made by substituting either part of $\mathrm{O}_{100^{-}}$ice milk mix or $\mathrm{B}_{100^{-}}$ice milk mix instead of $\mathrm{C}_{0}$ mix with percent $25 \%\left(\mathrm{OC}_{25} \& \mathrm{BC}_{25}\right), 50 \%\left(\mathrm{OC}_{50} \&\right.$ $\left.\mathrm{BC}_{50}\right)$ and $75 \%\left(\mathrm{OC}_{75} \& \mathrm{BC}_{75}\right)$ of the whole mix. Other one ice milk mix $\left(\mathrm{OBC}_{75}\right)$ was made from the three previous basic mixes at ratios $37.5 \% \mathrm{O}_{100^{-}}$ice milk mix: $37.5 \% \mathrm{~B}_{100^{-}}$ice milk mix: $25 \% \mathrm{C}_{0}$ mix (Table 1). All ice milk mixes were pasteurized in a double boiler at $85^{\circ} \mathrm{C}$ for $5 \mathrm{~min}$, cooled to $10^{\circ} \mathrm{C}$ in iced water bath and aged in cooler room at $4^{\circ} \mathrm{C}$ for $18 \mathrm{~h}$. After aging, all mixes were evaluated physically, flavored with $0.03 \%$ vanillin, frozen and whipped in a batch ice cream maker (STARMATIC V 500, Italy) at low speed for $12 \mathrm{~min}$. Afterwards, the ice milks were collected, packed into $120 \mathrm{ml}$ high density polyethylene cups and hardened at $18^{\circ} \mathrm{C}$ in a deep freezer (Zanussi ${ }^{\circledR}$ - ZFP21110 WA, ARE) for $24 \mathrm{~h}$ before physical and sensory evaluation. Three replicates of each treatment were made. Two ice milk mixes $\left(\mathrm{O}_{100^{-}}\right.$and $\mathrm{B}_{100^{-}}$ice milk mix) made from $100 \%$ oat's and barley's components were excluded from the ice milk processing because of their very high viscosity and very low whipping ability.

\subsection{Physical and chemical analysis}

The specific gravity and weight per gallon $(\mathrm{Kg})$ of ice milk mixes and ice milk samples were determined according to Winton (1958) and Burke (1947) respectively. Ice milk mixes

Table 1. Formulations of different ice milk mixes

\begin{tabular}{|c|c|c|c|c|c|c|c|c|c|c|}
\hline \multirow[t]{2}{*}{ Ingredients } & \multicolumn{10}{|c|}{ Mixes* } \\
\hline & $\mathrm{C}_{0}$ & $\mathbf{O}_{100}$ & $\mathbf{B}_{100}$ & $\mathrm{OC}_{25}$ & $\mathrm{OC}_{50}$ & $\mathrm{OC}_{75}$ & $\mathrm{BC}_{25}$ & $\mathrm{BC}_{50}$ & $\mathbf{B C}_{75}$ & $\mathbf{O B C}_{75}$ \\
\hline $\begin{array}{l}\text { Fresh buffalo } \\
\text { skim milk }\end{array}$ & 3.646 & ------- & 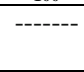 & 2.734 & 1.823 & 0.912 & 2.734 & 1.823 & 0.912 & 0.912 \\
\hline Fresh cream & 0.429 & 0.400 & 0.437 & 0.421 & 0.414 & 0.407 & 0.430 & 0.432 & 0.434 & 0.420 \\
\hline $\begin{array}{l}\text { Skim milk } \\
\text { powder }\end{array}$ & 0.255 & ----- & ----- & 0.192 & 0.128 & 0.064 & 0.192 & 0.128 & 0.064 & 0.064 \\
\hline Oat milk & ------ & 3.644 & ------ & 0.911 & 1.822 & 2.733 & 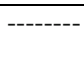 & $\begin{array}{l}----- \\
-\end{array}$ & $\begin{array}{l}------ \\
-\end{array}$ & 1.367 \\
\hline Barley milk & ------- & ------- & 3.631 & ----- & 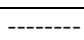 & -------- & 0.908 & 1.816 & 2.723 & 1.362 \\
\hline $\begin{array}{l}\text { White oat } \\
\text { powder }\end{array}$ & ------ & 0.286 & ------ & 0.072 & 0.143 & 0.214 & 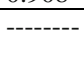 & ------ & ----- & 0.107 \\
\hline Barley powder & ------ & ------ & 0.262 & ------ & 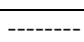 & -------- & 0.066 & 0.131 & 0.197 & 0.098 \\
\hline Sugar & 0.655 & 0.655 & 0.655 & 0.655 & 0.655 & 0.655 & 0.655 & 0.655 & 0.655 & 0.655 \\
\hline Stabilizer & 0.015 & 0.015 & 0.015 & 0.015 & 0.015 & 0.015 & 0.015 & 0.015 & 0.015 & 0.015 \\
\hline $\begin{array}{l}\text { Total weight } \\
\text { (kg) }\end{array}$ & 5.000 & 5.000 & 5.000 & 5.000 & 5.000 & 5.000 & 5.000 & 5.000 & 5.000 & 5.000 \\
\hline
\end{tabular}

* $\mathrm{C}_{0}$ : control mix, $\mathrm{O}_{100}$ : oat-ice milk mix, $\mathrm{B}_{100}$ : barley-ice milk mix, $\mathrm{OC}_{25}: 25 \%$ oat mix : $75 \%$ control mix, $\mathrm{OC}_{50}: 50 \%$ oat mix : $50 \%$ control mix, $\mathrm{OC}_{75}: 75 \%$ oat mix : $25 \%$ control mix, $\mathrm{BC}_{25}: 25 \%$ barley mix : $\mathbf{7 5 \%}$ control mix, $\mathrm{BC}_{50}: \mathbf{5 0 \%}$ barley mix : $\mathbf{5 0 \%}$ control mix,

$\mathrm{BC}_{75}: 75 \%$ barley mix : $25 \%$ control mix and $\mathrm{OBC}_{75}: 37.5 \%$ oat mix $: 37.5 \%$ barley mix : $25 \%$ control mix.

were analysed for the whipping ability using mixer at speed setting 2 with tow $3 \mathrm{~cm}$ whipping blades as described by Azzam (2003) and viscosity using a Brookfield viscometer (Brookfield DV-III, Brookfield Engineering Laboratories, Inc., USA) as described by Salama (2004). The overrun and melting rate of ice milk samples were determined according to Arbuckle (1986) and Bolliger et al. (2000) respectively. pH value of all ice milk mixes was measured after $24 \mathrm{~h}$ aging using a $\mathrm{pH}$ meter (Jenway model, USA). The total solids, fat, total protein, fibers and ash were determined according to the Official Method (A.O.A.C., 1990). A total carbohydrate was calculated by the difference of [dry matter - (protein + fat + ash)] according to Pearson (1976). All measurements were done in triplicates. The energetic content of ice milk samples was calculated from the caloric coefficient of proteins, lipids and carbohydrates as $4 \mathrm{kcal}^{-1}, 9 \mathrm{kcal} . \mathrm{g}^{-1}$ and $4 \mathrm{kcal} . \mathrm{g}^{-1}$, respectively.

\subsection{Sensory evaluation}

Hardened ice milk samples were sensually evaluated for flavor (50 points), body \& texture (30 points), melting property (10 points) and color \& appearance (10 points) by 12 staff members and post graduate students 
of Dairy Department in Faculty of Agriculture Cairo University according to the ice cream score card of Marshall et al., (2003). Total score of flavor, body \& texture, melting property and color \& appearance was defined as total acceptability (100 points).

\subsection{Economic evaluation}

Cost of production was calculated the prices of materials used to make ice milk based on common prices in local market.

\subsection{Statistical analysis}

The data were analyzed using ANOVA and treatment means were compared by using Duncan's Multiple Range test to determine the effects of treatments when the F-test was statistically significant at $P<0.05$ (Steel et al., 1997).

\section{Results And Discussion}

\subsection{Physical properties of ice milk mixes}

The lowest $\mathrm{pH}$ was noted for untreated ice milk mix $\left(\mathrm{C}_{0}\right)$ while ice milk mixes with oat components $\left(\mathrm{OC}_{25}, \mathrm{OC}_{50}, \mathrm{OC}_{75}\right.$, and $\left.\mathrm{O}_{100}\right)$ had comparatively higher $\mathrm{pH}$ followed by barley- ice milk mixes $\left(\mathrm{BC}_{25}, \mathrm{BC}_{50}\right.$, $\mathrm{BC}_{75}$ and $\left.\mathrm{B}_{100}\right)$, then oat/barley blend- ice milk mix $\left(\mathrm{OBC}_{75}\right)$ (Table 2). This increase in $\mathrm{pH}$ values of ice milk mixes with additives was correlated with the increase in oat milk or barley milk in experimental ice milk mixes probably due to the alkalinity normally measured in both oat milk and barley milk (Ali, 2012). Replacement of non fat milk solids with oat components or barley components caused a significant lowering in specific gravity (Sp.gr) and weight per gallon (Wt/gal) of all treated ice milk mixes except $\mathrm{OBC}_{75^{-}}$ice milk mix that showed non significant decrease in its $\mathrm{Sp}$.gr and $\mathrm{Wt} /$ gal compared to $\mathrm{C}_{0}$ mix (Table 2). Also it can be seen that oat- ice milk mixes $\left(\mathrm{OC}_{25}, \mathrm{OC}_{50}, \mathrm{OC}_{75}\right.$, and $\left.\mathrm{O}_{100}\right)$ had more lowering in their Sp.gr and Wt/gal than barley- ice milk mixes $\left(\mathrm{BC}_{25}, \mathrm{BC}_{50}, \mathrm{BC}_{75}\right.$, and $\left.\mathrm{B}_{100}\right)$. This decrease in the $\mathrm{Sp}$.gr and $\mathrm{Wt} / \mathrm{gal}$ was proportional to the replacement ratio and due to the low Sp.gr of both oat milk and barley milk (1.019 and 1.022, respectively) as compared to fresh skim milk (1.0391) used in ice milk making. The viscosity of untreated ice milk mix $\left(\mathrm{C}_{0}\right)$ was $94 \mathrm{cP}$. With an increase in rate of substituting of oat components or barley components, there was a corresponding increase in the viscosity of ice milk mix which reached maximum level at $100 \%$ replacement (2322 and $1459 \mathrm{cP}^{\text {for }} \mathrm{B}_{100^{-}}$ and $\mathrm{O}_{100^{-}}$ice milk mixes, respectively). But, barley- ice milk mixes had a significantly higher viscosity than the oat- ice milk mixes (Table 2). Data in Table (2) also indicated that the use of oat components and barley components in combined form in ice milk mix $\left(\mathrm{OBC}_{75}\right)$ led to increase in the viscosity of this mix $(545 \mathrm{cP})$. Thus, subrogation of oat or barley instead of non fat milk solids in ice milk mixes significantly affects the viscosity values of these mixtures. The high viscosity of treated ice milk mixes is due to the high content of starch and fibers in oat's and barley's grain. Gelatinization of starch is the most prominent change taking place during cooking of oat's and barley's grain when preparing their milks. Gelatinized starch has high water holding capacity and it can influence the rheological properties of ice milk mix (Rosalina et al., 2004, Mohan et al., 2005 and Patel et al., 2015). Soukoulis et al., (2009) reported that ice cream mixes containing oat's and wheat's fibers were characterized by significantly improved viscosities and strengthened shear thinning character likely induced both by the increase of serum concentration, due to water retention by the soluble fibers and by the presence of insoluble materials and high water retention ability, reaching up to $800 \%$.

Table 2. pH, viscosity, specific gravity (Sp.gr) and weight per gallon (Wt/gal) as physical properties of ice milk mixes $^{1}$ with and without added oat's and barley's components

\begin{tabular}{|c|c|c|c|c|}
\hline Ice milk mixes ${ }^{1}$ & pH & $\begin{array}{c}\text { Viscosity } \\
\text { (cP) }\end{array}$ & Sp. gr & $\begin{array}{c}\text { Wt/ gal } \\
\text { (kg) }\end{array}$ \\
\hline $\mathrm{C}_{0}$ & $6.35^{F}$ & $94.0^{\mathrm{J}}$ & $1.0749^{\mathrm{A}}$ & $4.8868^{\mathrm{A}}$ \\
\hline $\mathrm{OC}_{25}$ & $6.47^{\mathrm{B}}$ & $111.0^{1}$ & $1.0675^{\mathrm{C}}$ & $4.8530^{C}$ \\
\hline $\mathrm{OC}_{50}$ & $6.41^{\mathrm{D}}$ & $312.0^{\mathrm{G}}$ & $1.0589^{\mathrm{D}}$ & $4.8140^{\mathrm{D}}$ \\
\hline $\mathrm{OC}_{75}$ & $6.53^{\mathrm{A}}$ & $731.0^{\mathrm{D}}$ & $1.0516^{\mathrm{F}}$ & $4.7802^{\mathrm{F}}$ \\
\hline $\mathbf{O}_{100}$ & $6.44^{\mathrm{C}}$ & $1459.0^{\mathrm{B}}$ & $1.0460^{\mathrm{G}}$ & $4.7550^{\mathrm{G}}$ \\
\hline $\mathbf{B C}_{25}$ & $6.40^{\mathrm{D}}$ & $176.0^{\mathrm{H}}$ & $1.0715^{\mathrm{B}}$ & $4.8711^{\mathrm{B}}$ \\
\hline $\mathrm{BC}_{50}$ & $6.39^{\mathrm{E}}$ & $451.0^{\mathrm{F}}$ & $1.0678^{\mathrm{C}}$ & $4.8548^{\mathrm{C}}$ \\
\hline $\mathrm{BC}_{75}$ & $6.41^{\mathrm{D}}$ & $1110.0^{C}$ & $1.0587^{\mathrm{D}}$ & $4.8130^{D}$ \\
\hline $\mathbf{B}_{100}$ & $6.39^{\mathrm{E}}$ & $2322.0^{A}$ & $1.0551^{\mathrm{E}}$ & $4.7968^{\mathrm{E}}$ \\
\hline $\mathrm{OBC}_{75}$ & $6.39^{\mathrm{E}}$ & $545.0^{\mathrm{E}}$ & $1.0746^{\mathrm{A}}$ & $4.8790^{\mathrm{A}}$ \\
\hline LSD $(P<0.05)$ & 0.123 & 11.78 & 0.0031 & 0.125 \\
\hline
\end{tabular}

${ }^{1}$ see Table 1

A, B, C, D, E, F, G, H, I, J : Means with same letter in the same column are not significantly different.

Whipping abilities of experimental ice milk mixes varied among treatments. During 25 minutes whipping period, $\mathrm{C}_{0}$ mix showed significantly higher whipping ability $\left(146.1 \mathrm{~cm}^{3}\right)$ than any other mix, followed by $\mathrm{OC}_{25^{-}}$and $\mathrm{OC}_{50^{-}}$then, $\mathrm{BC}_{25^{-}}$followed by $\mathrm{BC}_{50^{-}}$and $\mathrm{OBC}_{75^{-}}$ice milk mix $(140.2,138.8,134.8,132.44$ and $132.54 \mathrm{~cm}^{3}$, respectively), whereas, the ability of $\mathrm{O}_{100^{-}}$and $\mathrm{B}_{100^{-}}$ice milk mixes for whipping reached to lowest level (114.51 and $112.60 \mathrm{~cm}^{3}$, respectively) compared to the other mixes (Table 3 ). The best time for whipping 
was 10 minutes (Mean: $140.6 \mathrm{~cm}^{3}$ ) compared to the other whipping times of all mixes except $\mathrm{O}_{100^{-}}, \mathrm{B}_{100^{-}}$and $\mathrm{OBC}_{75^{-}}$ice cream mixes. Statistical analysis of the interaction between the treatments and the whipping time showed that the $\mathrm{C}_{0}, \mathrm{OC}_{25^{-}}, \mathrm{OC}_{50^{-}}, \mathrm{BC}_{25^{-}}, \mathrm{OBC}_{75^{-}}$and $\mathrm{BC}_{50^{-}}$ice milk mix had the highest whipping abilities $\left(168.30,154.77,152.60,147.54,145.27\right.$ and $144.58 \mathrm{~cm}^{3}$, respectively) followed by $\mathrm{OC}_{75^{-}}$and $\mathrm{BC}_{75^{-}}$ice milk mixes (139.1 and $137 \mathrm{~cm}^{3}$, respectively) while, $\mathrm{O}_{100^{-}}$and $\mathrm{B}_{100^{-}}$ice milk mixes had the lowest (Table 3 and Fig. 1 A,B,C, respectively).

Table 3. Whipping ability as physical property of ice milk mixes ${ }^{1}$ with and without added oat's and barley's components.

\begin{tabular}{|c|c|c|c|c|c|c|c|}
\hline $\begin{array}{l}\text { Ice milk } \\
\text { mixes }^{1}\end{array}$ & 0 min & $5 \mathrm{~min}$ & $10 \mathrm{~min}$ & $15 \mathrm{~min}$ & $20 \mathrm{~min}$ & $25 \mathrm{~min}$ & \multirow{2}{*}{ Mean } \\
\hline & & & & & & & \\
\hline $\mathbf{C}_{0}$ & $\begin{array}{l}110.0^{\mathrm{a}} \\
\pm 0.0 \\
\end{array}$ & $147.3^{\mathrm{EF}} \quad \pm 0.02$ & $168.3^{\mathrm{A}} \quad \pm 5.10$ & $156.1^{\mathrm{B}} \quad \pm 1.95$ & $\begin{array}{l}150.9^{\mathrm{CDE}} \\
\pm 2.0\end{array}$ & $143.9^{\mathrm{FGHI}} \pm 2.91$ & $146.1^{\mathrm{A}} \pm 4.4$ \\
\hline $\mathrm{OC}_{25}$ & $\begin{array}{l}110.0^{\mathrm{a}} \\
\pm 0.0\end{array}$ & $\begin{array}{l}145.7^{\mathrm{F}} \\
\pm 4.43\end{array}$ & $154.8^{\mathrm{BC}} \quad \pm 0.19$ & $\begin{array}{l}149.9^{\mathrm{DE}} \\
\pm 0.54\end{array}$ & $143.8^{\text {FGHIJ }} \pm 1.77$ & $\begin{array}{l}136.9^{\mathrm{LMNO}} \\
\pm 1.58\end{array}$ & $140.2^{\mathrm{B}} \pm 3.6$ \\
\hline $\mathrm{OC}_{50}$ & $\begin{array}{l}110.0^{\mathrm{a}} \\
\pm 0.0\end{array}$ & $144.3^{\mathrm{FGH}} \pm 0.68$ & $152.6^{\mathrm{BCD}} \pm 0.65$ & $144.4^{\mathrm{FGH}} \pm 1.25$ & $140.9^{\mathrm{HIJKL}} \pm 0.03$ & $140.4^{\mathrm{HIJKL}} \pm 0.06$ & $138.8^{B} \pm 3.3$ \\
\hline $\mathrm{OC}_{75}$ & $\begin{array}{l}110.0^{\mathrm{a}} \\
\pm 0.0\end{array}$ & $\begin{array}{l}135.9^{\mathrm{MNOP}} \\
\pm 1.44\end{array}$ & $\begin{array}{l}139.1^{\text {KLMN }} \\
\pm 0.75\end{array}$ & $132.5^{\mathrm{PQR}} \pm 4.06$ & $\begin{array}{l}132.4^{\mathrm{PQR}} \\
\pm 0.12\end{array}$ & $\begin{array}{l}125.9^{\mathrm{TU}} \\
\pm 2.94\end{array}$ & $129.3^{\mathrm{E}} \pm 2.4$ \\
\hline $\mathbf{O}_{100}$ & $\begin{array}{l}110.0^{\mathrm{a}} \\
\pm 0.0\end{array}$ & $\begin{array}{l}121.4^{\mathrm{VW}} \\
\pm 1.03\end{array}$ & $\begin{array}{l}116.2^{X Y} \\
\pm 0.87\end{array}$ & $\begin{array}{l}114.9^{\mathrm{XYZ}} \\
\pm 0.41\end{array}$ & $\begin{array}{l}112.5^{\mathrm{YZa}} \\
\pm 0.74\end{array}$ & $\begin{array}{l}112.2^{\mathrm{YZa}} \\
\pm 0.59\end{array}$ & $114.5^{\mathrm{G}} \pm 0.9$ \\
\hline $\mathbf{B C}_{25}$ & $\begin{array}{l}110.0^{\mathrm{a}} \\
\pm 0.0\end{array}$ & $\begin{array}{l}141.4^{\mathrm{GHIJK}} \\
\pm 1.25\end{array}$ & $147.5^{\mathrm{EF}} \quad \pm 0.18$ & $\begin{array}{l}139.6^{\mathrm{JKLMN}} \\
\pm 0.35\end{array}$ & $\begin{array}{l}135.4^{\mathrm{NOP}} \\
\pm 0.98\end{array}$ & $\begin{array}{l}134.8^{\mathrm{OP}} \\
\pm 1.50\end{array}$ & $134.8^{C} \pm 2.9$ \\
\hline $\mathrm{BC}_{50}$ & $\begin{array}{l}110.0^{\mathrm{a}} \\
\pm 0.0\end{array}$ & $\begin{array}{l}139.9^{\text {IJKLM }} \\
\pm 0.72\end{array}$ & $144.6^{\mathrm{FGH}} \pm 0.74$ & $\begin{array}{l}137.5^{\text {KLMNO }} \\
\pm 0.79\end{array}$ & $\begin{array}{l}132.6^{\mathrm{PQR}} \\
\pm 0.35\end{array}$ & $130.1^{\text {QRST }} \pm 0.29$ & $132.4^{\mathrm{D}} \pm 2.7$ \\
\hline $\mathrm{BC}_{75}$ & $\begin{array}{l}110.0^{\mathrm{a}} \\
\pm 0.0\end{array}$ & $\begin{array}{l}132.0^{P Q R} \\
\pm 1.74 \\
\end{array}$ & $\begin{array}{l}137.0^{\mathrm{LMNO}} \\
\pm 3.15\end{array}$ & $\begin{array}{l}130.5^{\mathrm{QRS}} \\
\pm 1.10\end{array}$ & $\begin{array}{l}127.3^{\text {STU }} \\
\pm 0.87\end{array}$ & $\begin{array}{l}125.3^{\mathrm{UV}} \\
\pm 1.59\end{array}$ & $127.0^{\mathrm{F}} \pm 2.1$ \\
\hline $\mathbf{B}_{100}$ & $\begin{array}{l}110.0^{\mathrm{a}} \\
\pm 0.0\end{array}$ & $\begin{array}{l}118.1^{\mathrm{WX}} \\
\pm 1.41\end{array}$ & $\begin{array}{l}112.3^{\mathrm{YZa}} \\
\pm 0.25\end{array}$ & $\begin{array}{l}112.1^{\mathrm{YZa}} \\
\pm 0.34\end{array}$ & $\begin{array}{l}112.0^{\mathrm{YZa}} \\
\pm 0.43\end{array}$ & $\begin{array}{l}111.1^{\mathrm{Za}} \\
\pm 0.10\end{array}$ & $112.6^{\mathrm{H}} \pm 0.7$ \\
\hline $\mathrm{OBC}_{75}$ & $\begin{array}{l}110.0^{\mathrm{a}} \\
\pm 0.0 \\
\end{array}$ & $\begin{array}{l}128.9^{\mathrm{RSTU}} \\
\pm 1.70 \\
\end{array}$ & $133.7^{\mathrm{OPQ}} \pm 1.45$ & $\begin{array}{l}139.8^{\text {IJKLM }} \\
\pm 2.85 \\
\end{array}$ & $\begin{array}{l}145.3^{\mathrm{FG}} \\
\pm 3.81\end{array}$ & $\begin{array}{l}137.5^{\text {KLMNO }} \\
\pm 2.34\end{array}$ & $132.5^{\mathrm{D}} \pm 2.8$ \\
\hline Mean $^{3}$ & $110.0^{\mathrm{E}}$ & $135.5^{\mathrm{B}}$ & $140.6^{\mathrm{A}}$ & $135.7^{\mathrm{B}}$ & $133.3^{\mathrm{C}}$ & $129.8^{\mathrm{D}}$ & \\
\hline
\end{tabular}

\section{${ }^{1}$ see Table 1}

A, B, C, D, E, F, G, H,: Means with same letter in the column of Mean ${ }^{2}$ are not significantly different (LSD at $0.05=1.72$ )

A, B, C, D, E: Means with same letter in the row of Mean ${ }^{3}$ are not significantly different $($ LSD at $0.05=$ 1.33)

A, B, ......Z,a: Means with same letter in the Table of the interaction between whipping time and treatments are not significantly different $(\mathrm{LSD}$ at $0.05=4.21) \mathrm{SE} \pm$

This means, whipping ability decreased as oat components or barley components increased, as is clear that the mixes with higher oat or barley had more viscosities (Table 2) than the other mixes that having lower of oat or barley, so the decreased whipping ability is as a result of the increased viscosity. This means that there is interrelationship between viscosity and whipping ability (Fig 2). In this respect, Marshall and Arbuckle (1996) and Stanley et al., (1996) mentioned that ice cream mixes with high viscosities are known to have limited whipping ability. 


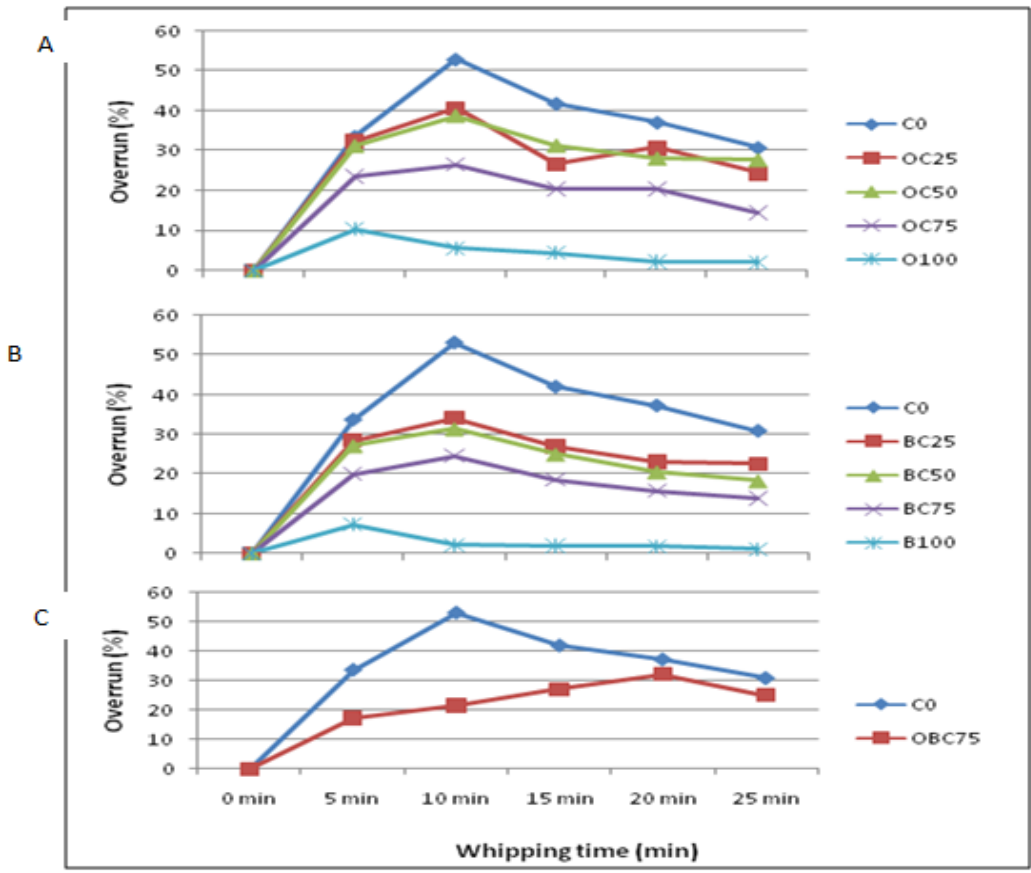

Fig 1. Mean percent overrun values (three replications) of ten ice milk mixes measured during 25 minutes whipping period and 5 min intervals.

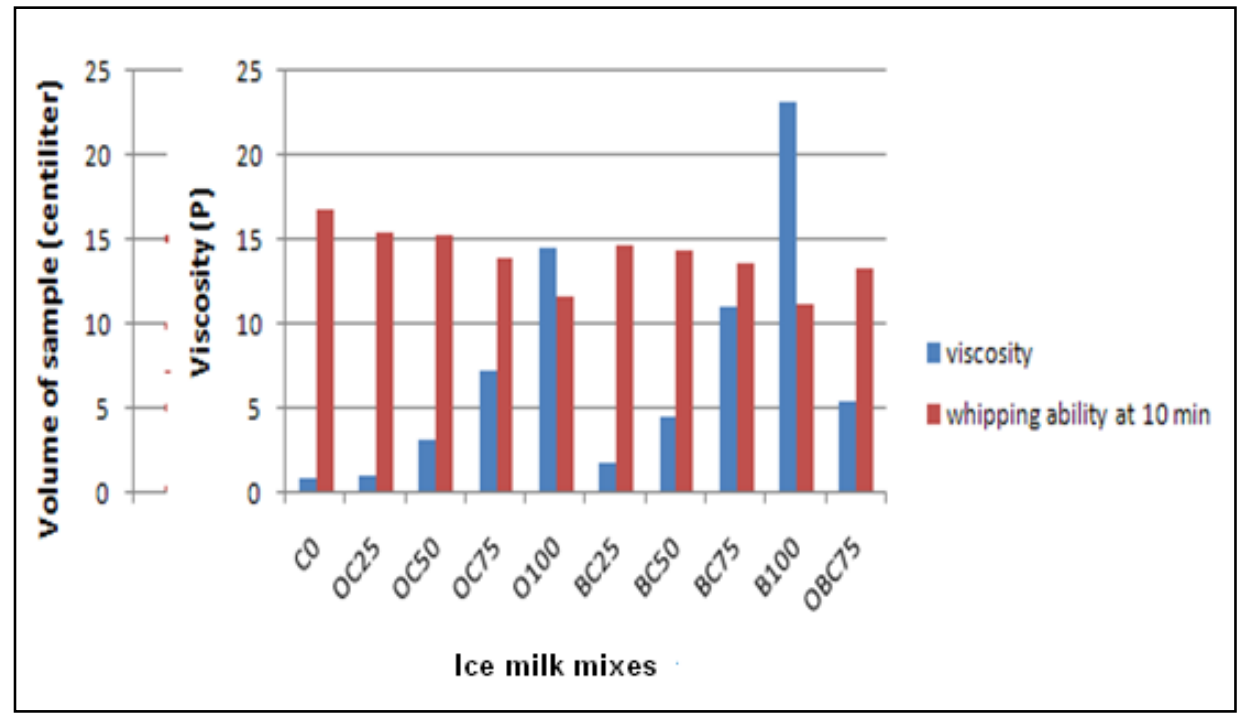

Fig 2. The interrelationship between viscosity and whipping ability of oat- and barley-ice milk mixes compared to control

From results of the physically evaluation of the experimental low fat ice cream mixes in this study, shows that the $\mathrm{O}_{100^{-}}$and $\mathrm{B}_{100^{-}}$ice milk mixes were the most poor mixes because of their very high viscosity and very low whipping ability, therefore they were excluded from the ice milk processing in future experiments.

\subsection{Physical properties of resultant ice milks:}

Overrun is a direct measure of the amount of air in ice milk that affects the quality of the product. The incorporation of too much air produces a fluffy ice milk and too little produces a soggy, heavy product (Arbuckle 1986 and Buck et al., 1986). Comparing the ice milks, it seems that the overrun significantly differed among treatments (Table 4). As can be noted that the amount and type of non dairy solids used to replace non fat milk solids in ice milk mixes were two factors negatively affected the overrun. The highest overrun was obtained from the untreated ice milk sample $\left(\mathrm{C}_{0}\right)$ as $59.95 \%$, followed by $\mathrm{OC}_{25^{-}}$ice milk $(55.61 \%)$ then $\mathrm{BC}_{25}-$ ice milk $(49.91 \%)$ and $\mathrm{OC}_{50}$ - ice milk $(48.01 \%)$ while the lowest overrun was for $\mathrm{BC}_{75}$ - ice milk $(17.85 \%)$. So, incorporation of oat or barley causes decrement in overrun values of treated ice milks. It is due to the increase in the viscosity, which causes a less air incorporation (Fig 3). But barley components had the greatest influence in 
overrun compared to oat components. Similarly, Hwang et al., (2009) reported that overrun values of grape wine lee ice cream samples were found to be lower compared to those of untreated sample because of increment in apparent viscosity of these samples.

Both Sp.gr and Wt/gal tended to increase with the proportional increase of oat or barley level in resultant ice milks compared to those of untreated ice milk $\left(\mathrm{C}_{0}\right)$ (Table 4). This increase may be due to the high contribution of oat's and barley's components in the instability of air phase of ice cream mix during freezing and whipping. These results are in agreement with the results reported by both Erkaya et al., (2011) for ice cream containing Cape gooseberry, Farahat et al., (2011) for functional ice cream fortified with date pulp and ElSamahy et al., (2015) for low fat ice cream containing Cactus pear pulp.

Table 4. Overrun, specific gravity (Sp.gr) and weight per gallon (Wt/gal) as physical properties of ice milks with and without added oat's and barley's components

\begin{tabular}{|c|c|c|c|}
\hline Ice milks ${ }^{1}$ & $\begin{array}{c}\text { Overrun } \\
(\%)\end{array}$ & Sp.gr & $\begin{array}{c}\text { Wt/ gal } \\
\text { (kg) }\end{array}$ \\
\hline $\mathbf{C}_{0}$ & $\begin{array}{c}59.95^{\mathrm{A}} \\
\pm 1.33\end{array}$ & $\begin{array}{l}0.6722^{\mathrm{E}} \\
\pm 0.0051\end{array}$ & $\begin{array}{l}3.06^{\mathrm{E}} \\
\pm 0.02\end{array}$ \\
\hline $\mathrm{OC}_{25}$ & $\begin{array}{l}55.61^{\mathrm{B}} \\
\pm 0.26\end{array}$ & $\begin{array}{l}0.6860^{\mathrm{E}} \\
\pm 0.0011\end{array}$ & $\begin{array}{l}3.12^{\mathrm{E}} \\
\pm 0.00\end{array}$ \\
\hline $\mathrm{OC}_{50}$ & $\begin{array}{l}48.01^{\mathrm{C}} \\
\pm 1.54\end{array}$ & $\begin{array}{l}0.7157^{\mathrm{D}} \\
\pm 0.0075\end{array}$ & $\begin{array}{l}3.25^{\mathrm{D}} \\
\pm 0.03\end{array}$ \\
\hline $\mathrm{OC}_{75}$ & $\begin{array}{l}24.90^{\mathrm{E}} \\
\pm 1.42\end{array}$ & $\begin{array}{l}0.8423^{\mathrm{B}} \\
\pm 0.0098\end{array}$ & $\begin{array}{l}3.83^{\mathrm{B}} \\
\pm 0.04\end{array}$ \\
\hline $\mathbf{B C}_{25}$ & $\begin{array}{l}49.91^{\mathrm{C}} \\
\pm 0.65\end{array}$ & $\begin{array}{l}0.7195^{\mathrm{D}} \\
\pm 0.0031\end{array}$ & $\begin{array}{l}3.27^{\mathrm{D}} \\
\pm 0.01\end{array}$ \\
\hline $\mathrm{BC}_{50}$ & $\begin{array}{l}26.67^{\mathrm{E}} \\
\pm 1.39\end{array}$ & $\begin{array}{l}0.8434^{\mathrm{B}} \\
\pm 0.0090\end{array}$ & $\begin{array}{l}3.83^{\mathrm{B}} \\
\pm 0.04\end{array}$ \\
\hline $\mathbf{B C}_{75}$ & $\begin{array}{l}17.85^{\mathrm{F}} \\
\pm 0.45\end{array}$ & $\begin{array}{l}0.8985^{\mathrm{A}} \\
\pm 0.0029\end{array}$ & $\begin{array}{l}4.08^{\mathrm{A}} \\
\pm 0.01\end{array}$ \\
\hline $\mathrm{OBC}_{75}$ & $\begin{array}{l}37.71^{\mathrm{D}} \\
\pm 1.21\end{array}$ & $\begin{array}{l}0.7795^{\mathrm{C}} \\
\pm 0.0066\end{array}$ & $\begin{array}{l}3.54^{\mathrm{C}} \\
\pm 0.03\end{array}$ \\
\hline LSD $(P<0.05)$ & 3.50 & 0.0198 & 0.09 \\
\hline
\end{tabular}

A, B, C, D, E, F: Means with same letter in the same column are not significantly different. SE \pm see Table 1.

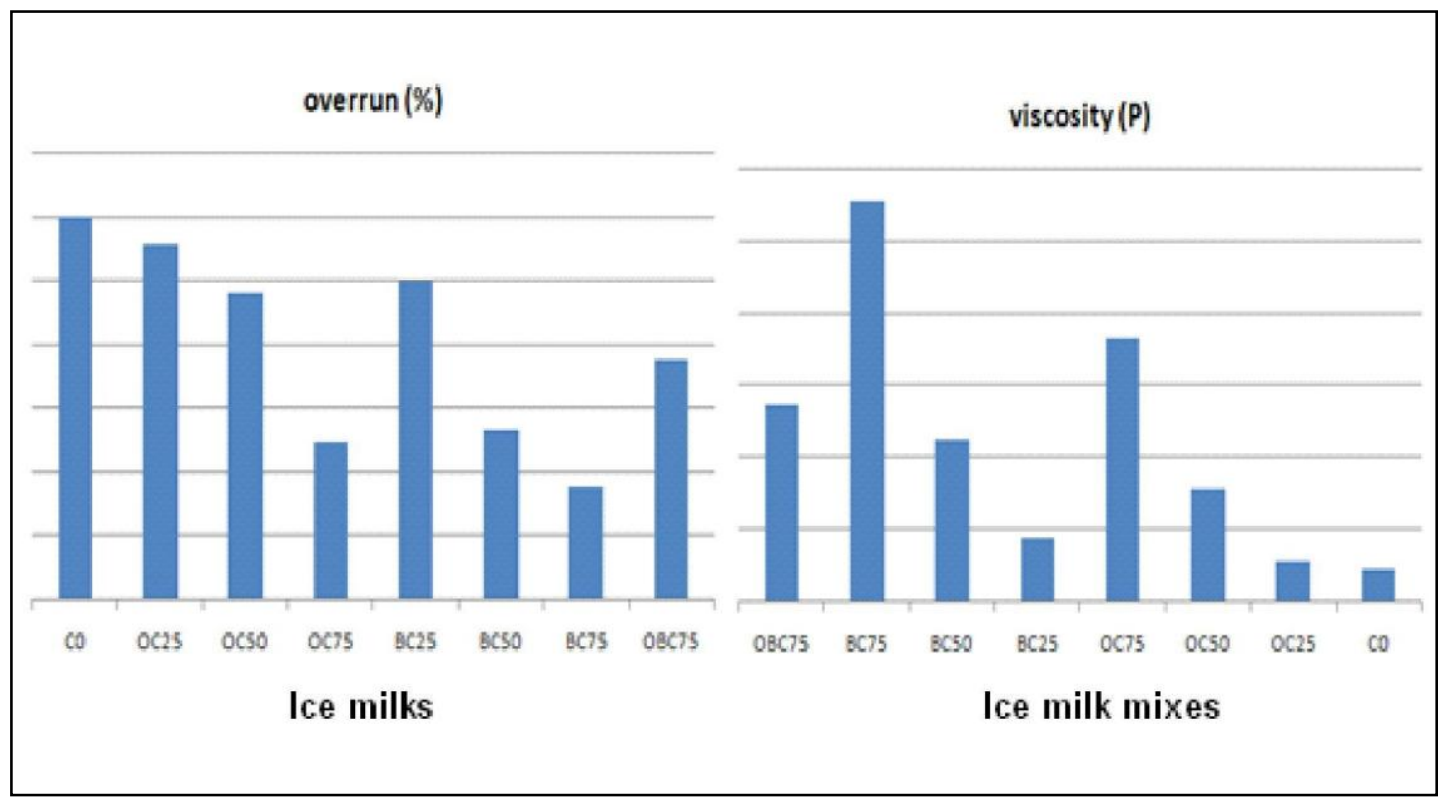

Fig 3. The interrelationship between viscosity of oat- and barley- ice milk mixes and overrun of their ice milks compared to control.

Meltdown rate of resultant ice milk samples expressed as weight of melted ice milk during 90 minutes at intervals of 15 minutes is recorded in Table (5). The recorded data indicated that the replacement of non fat milk solids with different amounts of oat or barley significantly decreased the meltdown rate of resultant ice milk. Ice milk samples with oat lost their shape and melted more quickly than those with barley. At all the measuring times, the maximum meltdown rate (Mean $=36.36 \mathrm{~g}$ melted ice milk) was noted in $\mathrm{C}_{0}$ while $\mathrm{BC}_{75^{-}}$ ice milk sample had the minimum meltdown rate (Mean $=9.54 \mathrm{~g}$ melted ice milk). A probable cause for this 
behavior was the impact of fibers and starch in oat and barley on the viscosity of the treated mixes. The increased viscosity of the ice milk mixes made with oat or barley contributed to the increased resistance of ice milk to melt (Fig 4) (Arbuckle 1986, Das et al., 1989 and Marshall et al., 2003). These results were in agreement with those reported by Patel et al., (2015).

Patel et al., (2015) found that ice creams with the high level of gelatinized malted ragi flour roasted in butter (MRB) had the highest melting resistance. They attributed that to fibers and starch in finger millet (Ragi) which may act as stabilizers due to their high capacity for binding water and thus causes the increased viscosity of ice cream mixes and the increased melting resistance of resultant ice cream.

Table 5. Meltdown rate as physical property of ice milks ${ }^{1}$ with and without added oat's and barley's components

\begin{tabular}{|c|c|c|c|c|c|c|c|}
\hline & & & Melti & g time & & & \\
\hline \multirow[t]{2}{*}{ Ice milks $^{1}$} & $15 \mathrm{~min}$ & $30 \mathrm{~min}$ & $\overline{45} \min$ & $60 \mathrm{~min}$ & $75 \mathrm{~min}$ & $90 \mathrm{~min}$ & \\
\hline & & & \multicolumn{3}{|c|}{ Melted ice milk (g) } & & Mean $^{2}$ \\
\hline $\mathrm{C}_{0}$ & $\begin{array}{l}6.32^{\mathrm{UVW}} \\
\pm 0.40\end{array}$ & $\begin{array}{l}19.98^{\mathrm{NO}} \\
\pm 0.76\end{array}$ & $33.69^{\mathrm{JK}} \quad \pm 1.30$ & $\begin{array}{l}44.85^{\mathrm{DE}} \\
\pm 0.96\end{array}$ & $\begin{array}{l}55.55^{\bar{B}} \\
\pm 0.21\end{array}$ & $\begin{array}{l}57.75^{\mathrm{A}} \\
\pm 0.09\end{array}$ & $36.36^{-1} \pm 4.8$ \\
\hline $\mathrm{OC}_{25}$ & $3.22^{\mathrm{X}} \pm 0.16$ & $\begin{array}{l}8.64^{\mathrm{ST}} \\
\pm 0.15\end{array}$ & $23.89^{\mathrm{M}} \quad \pm 0.47$ & $\begin{array}{ll}38.57^{\mathrm{GH}} \quad \pm \\
0.56\end{array}$ & $45.65^{\mathrm{DE}} \pm 0.59$ & $50.26^{\mathrm{C}} \pm 0.46$ & $28.37^{\mathrm{B}} \pm 4.3$ \\
\hline $\mathrm{OC}_{50}$ & $\begin{array}{l}2.04^{X} \\
\pm 0.10\end{array}$ & $\begin{array}{l}6.43^{\mathrm{UVW}} \\
\pm 0.25\end{array}$ & $16.84^{\mathrm{P}} \pm 0.26$ & $26.55^{\mathrm{L}} \pm 0.65$ & $39.27^{\mathrm{G}} \pm 0.52$ & $47.92^{\mathrm{D}} \pm 0.47$ & $23.17^{\mathrm{D}} \pm 4.0$ \\
\hline $\mathrm{OC}_{75}$ & $1.49^{\mathrm{X}} \pm 0.20$ & $\begin{array}{l}2.8^{\mathrm{X}} \\
\pm 0.12 \\
\end{array}$ & $\begin{array}{l}7.03^{\mathrm{TUVW}} \\
\pm 0.64\end{array}$ & $\begin{array}{l}10.16^{\mathrm{RS}} \\
\pm 0.61 \\
\end{array}$ & $16.80^{P} \pm 1.05$ & $\begin{array}{l}32.05^{\mathrm{K}} \\
\pm 1.36 \\
\end{array}$ & $11.72^{\mathrm{F}} \pm 2.5$ \\
\hline $\mathrm{BC}_{25}$ & $2.75^{\mathrm{X}} \pm 0.18$ & $\begin{array}{l}8.21^{\text {STUV }} \\
\pm 0.21\end{array}$ & $19.19^{\mathrm{O}} \quad \pm 0.42$ & $\begin{array}{l}36.96^{\mathrm{HI}} \\
\pm 2.72\end{array}$ & $42.04^{\mathrm{F}} \pm 1.04$ & $45.99^{\mathrm{DE}} \pm 0.65$ & $\begin{array}{l}25.86^{\mathrm{C}} \\
\pm 4.1\end{array}$ \\
\hline $\mathrm{BC}_{50}$ & $1.26^{\mathrm{X}} \pm 0.06$ & $\begin{array}{l}5.38^{\mathrm{W}} \\
\pm 0.08\end{array}$ & $15.22^{\mathrm{PQ}} \quad \pm 0.24$ & $\begin{array}{l}21.92^{\mathrm{MN}} \\
\pm 0.83\end{array}$ & $35.27^{\mathrm{IJ}} \pm 0.68$ & $38.72^{\mathrm{GH}} \pm 0.96$ & $19.63^{\mathrm{E}} \pm 3.4$ \\
\hline $\mathrm{BC}_{75}$ & $1.54^{\mathrm{X}} \pm 0.40$ & $\begin{array}{l}2.73^{\mathrm{X}} \\
\pm 0.05\end{array}$ & $6.20^{\mathrm{VW}} \pm 0.14$ & $8.43^{\mathrm{STU}} \pm 0.39$ & $12.26^{\mathrm{R}} \pm 0.60$ & $26.06^{\mathrm{L}} \pm 0.08$ & $\begin{array}{l}9.54^{\mathrm{G}} \\
\pm 2.0\end{array}$ \\
\hline $\mathrm{OBC}_{75}$ & $2.52^{\mathrm{X}} \pm 0.04$ & $\begin{array}{l}14.57^{Q} \\
\pm 0.23\end{array}$ & $27.64^{\mathrm{L}} \pm 0.51$ & $\begin{array}{l}34.71^{\mathrm{IJ}} \\
\pm 1.71\end{array}$ & $35.94^{\text {IJ }} \pm 1.46$ & $37.26^{\mathrm{HI}} \pm 0.40$ & $25.44^{\mathrm{C}} \pm 4.0$ \\
\hline
\end{tabular}

see Table 1

$\mathrm{A}, \mathrm{B}, \mathrm{C}, \mathrm{D}, \mathrm{E}, \mathrm{F}, \mathrm{G}, \mathbf{1}$ Means with same letter in the column of Mean ${ }^{2}$ are not significantly different $(\mathrm{LSD}$ at $0.05=$ 0.87)

A,B,........X: Means with same latter in the Table of the interaction between melting time and trea- tments are not significantly different (LSD at $0.05=2.12) \mathrm{SE} \pm$.

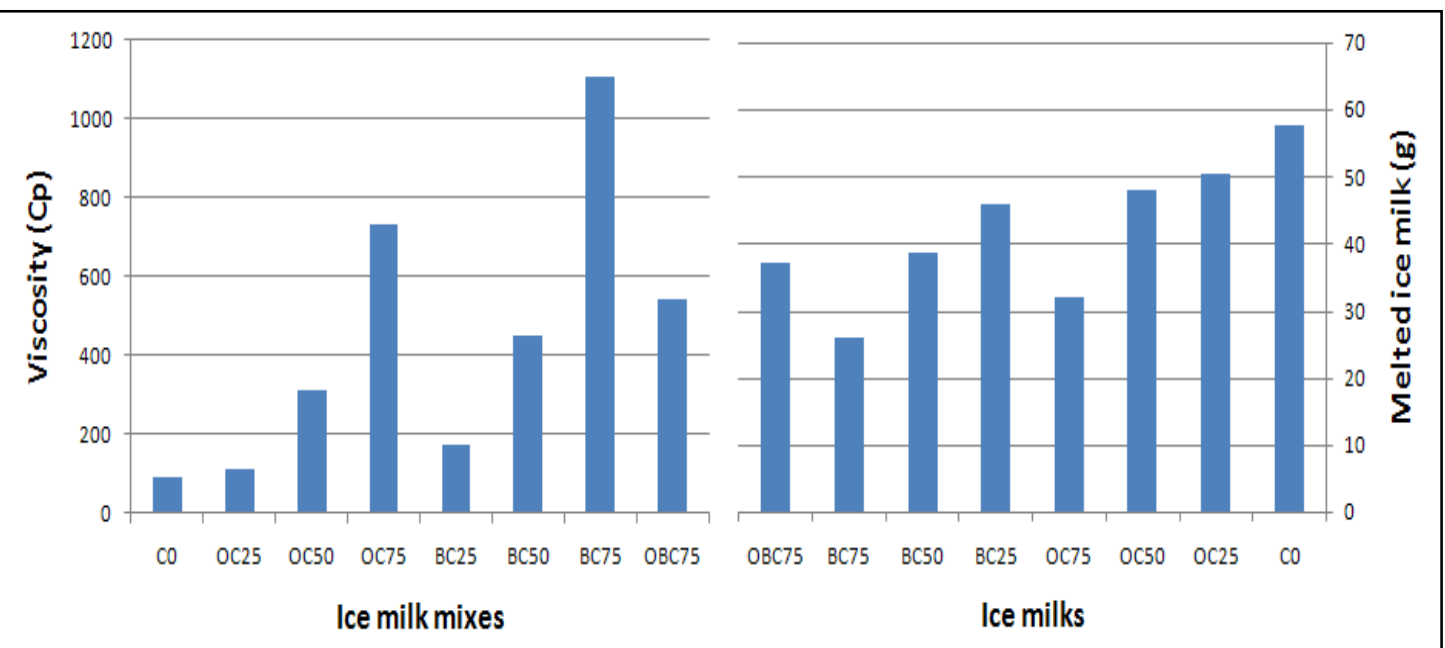

Fig. 4. The interrelationship between viscosity of oat- and barley- ice milk mixes and meltdown rate of their ice milks compared to control at 90 minutes.

\subsection{Sensory evaluation}

The panel scores to ice milk samples were affected by replacement levels of oat's and barley's components with non fat milk solids as mentioned by the judges (Table 6). Although, oat- and barley- ice milks were found to have less smoothness and less whiteness, especially barley- ice milk samples, than the control sample $\left(\mathrm{C}_{0}\right)$, however, no significant difference for textural appearance and color was emphasized between $\mathrm{BC}_{25}$ - ice milk and $\mathrm{C}_{0}$. 
The panelists noted that $\mathrm{BC}_{75^{-}}$ice milk melt slowly in the mouth than other treatments, no significant differences were observed in melting of $\mathrm{BC}_{25^{-}}, \mathrm{OC}_{25^{-}}, \mathrm{OBC}_{75^{-}}$ice milk or $\mathrm{C}_{0}$, while the sensory panel scores showed slight significant differences between $\mathrm{OC}_{50^{-}}, \mathrm{OC}_{75^{-}}$or $\mathrm{BC}_{50^{-}}$ice milk and $\mathrm{C}_{0}$. No significant differences in body and texture were detected between $\mathrm{BC}_{25^{-}}$and $\mathrm{C}_{0}$ ice milk samples. The texture of ice milks where the levels of oat's and barley's components have been higher reported to be harder than for ice milk samples of lower oat or barley. $\mathrm{BC}_{25^{-}}, \mathrm{OC}_{25^{-}}$and $\mathrm{OC}_{50^{-}}$ice milk were scored significantly higher in vanilla flavor than that of $\mathrm{OC}_{75^{-}}, \mathrm{BC}_{75^{-}}, \mathrm{BC}_{50^{-}}$and $\mathrm{OBC}_{75^{-}}$ice milk. Starchy taste of treated samples was observed to be evident as the oat or barley content of the ice milk was increased. The highest scores for general acceptability were recorded for $\mathrm{C}_{0}$ and $\mathrm{BC}_{25^{-}}$ice milk followed by $\mathrm{OC}_{25^{-}}$, and $\mathrm{BC}_{50^{-}}$, then $\mathrm{OC}_{50^{-}}$ice milk while, the least accepted was $\mathrm{BC}_{75^{-}}$ ice milk (Table 6 and Fig 5).

Table 6. Sensory evaluation results of ice milks ${ }^{1}$ with and without added oat's and barley's components

\begin{tabular}{|c|c|c|c|c|c|}
\hline Ice milks ${ }^{1}$ & $\begin{array}{c}\text { Flavor } \\
\mathbf{5 0}\end{array}$ & $\begin{array}{l}\text { Body \& } \\
\text { texture } 30\end{array}$ & $\begin{array}{c}\text { Melting } \\
\text { property } 10\end{array}$ & $\begin{array}{c}\text { Color \& appearance } \\
10\end{array}$ & $\begin{array}{c}\text { overall acceptability } \\
100\end{array}$ \\
\hline $\mathrm{C}_{0}$ & $\begin{array}{l}46.0^{\mathrm{A}} \\
\pm 0.8\end{array}$ & $\begin{array}{l}27.0^{\mathrm{A}} \\
\pm 0.7\end{array}$ & $\begin{array}{c}8.3^{\mathrm{A}} \\
\pm 0.2\end{array}$ & $\begin{array}{r}8.7^{\mathrm{A}} \\
\pm 0.2\end{array}$ & $\begin{array}{c}90.0^{\mathrm{A}} \\
\pm 0.7\end{array}$ \\
\hline $\mathrm{OC}_{25}$ & $\begin{array}{l}44.3^{\mathrm{AB}} \\
\pm 0.8\end{array}$ & $\begin{array}{l}23.3^{\mathrm{C}} \\
\pm 0.9\end{array}$ & $\begin{array}{l}8.0^{\mathrm{A}} \\
\pm 0.4\end{array}$ & $\begin{array}{l}8.3^{\mathrm{AB}} \\
\pm 0.2\end{array}$ & $\begin{array}{l}84.0^{\mathrm{B}} \\
\pm 0.5\end{array}$ \\
\hline $\mathrm{OC}_{50}$ & $\begin{array}{c}43.7^{\mathrm{AB}} \\
\pm 0.5\end{array}$ & $\begin{array}{l}24.3^{\mathrm{B}} \\
\pm 0.6\end{array}$ & $\begin{array}{l}7.7^{\mathrm{AB}} \\
\pm 0.2\end{array}$ & $\begin{array}{c}7.7^{\mathrm{B}} \\
\pm 0.2\end{array}$ & $\begin{array}{l}83.3^{\mathrm{BC}} \\
\pm 1.0\end{array}$ \\
\hline $\mathrm{OC}_{75}$ & $\begin{array}{l}42.7^{\mathrm{B}} \\
\pm 0.9\end{array}$ & $\begin{array}{l}23.7^{C} \\
\pm 0.8\end{array}$ & $\begin{array}{l}7.7^{\mathrm{AB}} \\
\pm 0.2\end{array}$ & $\begin{array}{r}7.7^{\mathrm{B}} \\
\pm 0.2\end{array}$ & $\begin{array}{l}81.7^{\mathrm{CD}} \\
\pm 0.7\end{array}$ \\
\hline $\mathrm{BC}_{25}$ & $\begin{array}{c}44.7^{\mathrm{AB}} \\
\pm 0.5\end{array}$ & $\begin{array}{l}27.0^{\mathrm{A}} \\
\pm 0.4\end{array}$ & $\begin{array}{r}8.3^{\mathrm{A}} \\
\pm 0.2\end{array}$ & $\begin{array}{l}9.0^{\mathrm{A}} \\
\pm 0.4\end{array}$ & $\begin{array}{l}89.0^{\mathrm{A}} \\
\pm 0.7\end{array}$ \\
\hline $\mathrm{BC}_{50}$ & $\begin{array}{l}42.3^{\mathrm{B}} \\
\pm 0.6\end{array}$ & $\begin{array}{c}26.0^{\mathrm{AB}} \\
\pm 0.8\end{array}$ & $\begin{array}{l}7.7^{\mathrm{AB}} \\
\pm 0.2\end{array}$ & $\begin{array}{l}7.7^{\mathrm{B}} \\
\pm 0.6\end{array}$ & $\begin{array}{l}83.7^{\mathrm{B}} \\
\pm 1.0\end{array}$ \\
\hline $\mathrm{BC}_{75}$ & $\begin{array}{l}42.7^{\mathrm{B}} \\
\pm 0.2\end{array}$ & $\begin{array}{c}25.3^{\mathrm{ABC}} \\
\pm 0.6\end{array}$ & $\begin{array}{r}7.0^{\mathrm{B}} \\
\pm 0.4\end{array}$ & $\begin{array}{r}6.3^{\mathrm{C}} \\
\pm 0.2\end{array}$ & $\begin{array}{l}81.3^{\mathrm{D}} \\
\pm 1.0\end{array}$ \\
\hline $\mathrm{OBC}_{75}$ & $\begin{array}{l}42.3^{\mathrm{B}} \\
\pm 1.5\end{array}$ & $\begin{array}{c}24.7^{\mathrm{BC}} \\
\pm 0.2\end{array}$ & $\begin{array}{r}8.0^{\mathrm{A}} \\
\pm 0.4\end{array}$ & $\begin{array}{r}7.7^{\mathrm{B}} \\
\pm 0.2\end{array}$ & $\begin{array}{l}82.7^{\mathrm{BCD}} \\
\pm 0.7\end{array}$ \\
\hline LSD $(P<0.05)$ & 2.62 & 2.05 & 0.89 & 0.88 & 1.85 \\
\hline
\end{tabular}

A, B, C, D: Means with same letter in the same column are not significantly different. SE \pm

1 see Table 1

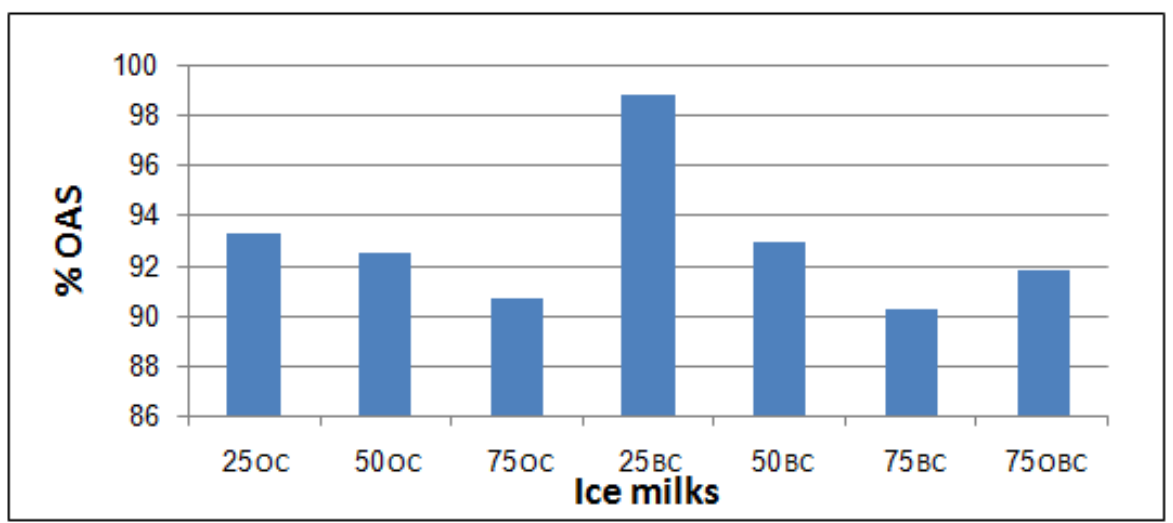

Fig. 5. The percentage of overall acceptability score of treated ice milks (\% OAS) from overall acceptability score of the control

From results of the sensory evaluation of the resultant ice milks, $\mathrm{BC}_{25^{-}}, \mathrm{OC}_{25^{-}}, \mathrm{BC}_{50^{-}}, \mathrm{OC}_{50^{-}}$and $\mathrm{OBC}_{75^{-}}$ice milk, were selected for future experiments compared to $\mathrm{C}_{0}$.

\subsection{Economic evaluation}

Table (7) summarizes the production cost of one liter of most acceptable ice milks compared to the control. A few increase in the cost of a liter of $\mathrm{BC}_{50^{-}}, \mathrm{OC}_{25^{-}}$or $\mathrm{OBC}_{75^{-}}$ice milk $(0.23-0.26 \mathrm{~L} . \mathrm{E})$ for the cost of a liter of $\mathrm{C}_{0}(6.63 \mathrm{~L} . \mathrm{E})$ whereas the cost of a liter of $\mathrm{BC}_{25^{-}}$ice milk was lower than that of control by $3.17 \%$. The cost of a liter of $\mathrm{OC}_{50^{-}}$ice milk was the highest among all treatments (7.32 L.E).Therefore, $\mathrm{BC}_{25^{-}}, \mathrm{BC}_{50^{-}}, \mathrm{OC}_{25^{-}}$ and $\mathrm{OBC}_{75^{-}}$ice milk can be produced and circulated industrially. 
Table 7. Production cost of ice milks ${ }^{1}$ with added oat's and barley's components compared to the control.

\begin{tabular}{|c|c|c|c|c|c|c|c|}
\hline \multirow{3}{*}{ Ingredients } & \multirow{3}{*}{$\begin{array}{c}\text { Price } \\
\text { L.E/kg }\end{array}$} & \multicolumn{6}{|c|}{ Ice milk mixes ${ }^{1}$} \\
\hline & & $\mathrm{C}_{0}$ & $\mathrm{OC}_{25}$ & $\mathrm{OC}_{50}$ & $\mathrm{BC}_{25}$ & $\mathrm{BC}_{50}$ & $\mathrm{OBC}_{75}$ \\
\hline & & \multicolumn{6}{|c|}{ Price of ingredients (L.E) } \\
\hline Fresh buffalo skim milk & 4.00 & 14.60 & 10.94 & 7.30 & 10.94 & 7.30 & 3.65 \\
\hline Fresh cream & 45.00 & 19.31 & 18.95 & 18.63 & 19.35 & 19.44 & 18.90 \\
\hline Skim milk powder & 30.00 & 7.65 & 5.76 & 3.84 & 5.76 & 3.84 & 1.92 \\
\hline Oat milk & 5.00 & 0.00 & 4.56 & 9.11 & 0.00 & 0.00 & 6.84 \\
\hline Barley milk & 1.00 & 0.00 & 0.00 & 0.00 & 0.91 & 1.82 & 1.37 \\
\hline White oat powder & 32.00 & 0.00 & 2.30 & 4.58 & 0.00 & 0.00 & 3.42 \\
\hline Barley powder & 4.00 & 0.00 & 0.00 & 0.00 & 0.26 & 0.52 & 0.39 \\
\hline Sugar & 5.00 & 3.30 & 3.30 & 3.30 & 3.30 & 3.30 & 3.30 \\
\hline Stabilizer & 300.00 & 4.50 & 4.50 & 4.50 & 4.50 & 4.50 & 4.50 \\
\hline Total cost (L.E/ 5 kg mix) & - & 49.36 & 50.31 & 51.26 & 45.02 & 40.72 & 44.29 \\
\hline Overrun $\%$ & ב-ב- & 60 & 56 & 48 & 50 & 27 & 38 \\
\hline $\begin{array}{l}\text { Total cost }(\mathrm{L} . \mathrm{E} / \mathrm{lL} \text { ice } \\
\text { cream) }\end{array}$ & & 6.63 & 6.87 & 7.32 & 6.42 & 6.86 & 6.89 \\
\hline overall acceptability (100) & & 90 & 84 & 83 & 89 & 84 & 83 \\
\hline Suitable choice & & & $\sqrt{1}$ & & $\sqrt{1}$ & $\sqrt{ }$ & $\sqrt{ }$ \\
\hline
\end{tabular}

\subsection{Nutritional evaluation}

\subsubsection{Chemical composition}

The average compositional values of most acceptable ice milks $\left(\mathrm{BC}_{25}, \mathrm{BC}_{50}, \mathrm{OC}_{25}\right.$ and $\left.\mathrm{OBC}_{75}\right)$ as affected by different replacement levels of non fat milk solids with oat's or/and barley's components are presented in Table (8). Total solids and fat contents of all ice creams were within the limited levels of the standards given by the Egyptian Standards (2005). With increasing replacement levels of fresh skimmed milk and skimmed milk powder with oat or/and barley, the contents of protein and ash of the resultant ice milks decreases, while their total carbohydrate content was increased compared to the control $\left(\mathrm{C}_{0}\right)$. This is due to oat's and barley's milk and oat's and barley's powder used in treated ice milk mixes had the lowest amount of protein and ash contents and the highest amount of carbohydrates compared to fresh skimmed milk and skimmed milk powder.

Table 8. Chemical composition of most acceptable ice milks ${ }^{*}$

\begin{tabular}{|c|c|c|c|c|c|}
\hline \multirow{2}{*}{ Type of ice milk* } & \multicolumn{5}{|c|}{ Constituents (\%) } \\
\hline & Total solids & Fat & Protein ${ }^{* *}$ & Ash & Carbohydrates \\
\hline \multirow[t]{2}{*}{$\mathbf{C}_{0}$} & $29.41^{\mathrm{A}}$ & $4.0^{\mathrm{AB}}$ & $4.565^{\mathrm{A}}$ & $0.971^{\mathrm{A}}$ & $19.874^{\mathrm{D}}$ \\
\hline & \pm 0.006 & \pm 0.058 & \pm 0.022 & \pm 0.008 & \pm 0.059 \\
\hline \multirow[t]{2}{*}{$\mathrm{OC}_{25}$} & $29.42^{\mathrm{A}}$ & $3.9^{\mathrm{B}}$ & $3.889^{\mathrm{B}}$ & $0.821^{\mathrm{C}}$ & $20.810^{C}$ \\
\hline & \pm 0.006 & \pm 0.055 & \pm 0.028 & \pm 0.006 & \pm 0.046 \\
\hline \multirow[t]{2}{*}{$\mathbf{B C}_{25}$} & $29.42^{\mathrm{A}}$ & $3.9^{\mathrm{B}}$ & $3.803^{C}$ & $0.879^{\mathrm{B}}$ & $20.838^{C}$ \\
\hline & \pm 0.005 & \pm 0.048 & \pm 0.003 & \pm 0.007 & \pm 0.054 \\
\hline \multirow[t]{2}{*}{$\mathrm{BC}_{50}$} & $29.38^{B}$ & $4.1^{\mathrm{A}}$ & $3.007^{\mathrm{D}}$ & $0.774^{\mathrm{D}}$ & $21.499^{\mathrm{B}}$ \\
\hline & \pm 0.005 & \pm 0.058 & \pm 0.005 & \pm 0.006 & \pm 0.068 \\
\hline \multirow[t]{2}{*}{$\mathrm{OBC}_{75}$} & $29.41^{\mathrm{A}}$ & $4.0^{\mathrm{AB}}$ & $2.309^{\mathrm{E}}$ & $0.629^{\mathrm{E}}$ & $22.472^{\mathrm{A}}$ \\
\hline & \pm 0.006 & \pm 0.33 & \pm 0.006 & \pm 0.0018 & \pm 0.014 \\
\hline LSD 0.05 & 0013 & 0.126 & 0.041 & 0.026 & 0.116 \\
\hline
\end{tabular}

see Table 1

*** Total protein of $\mathrm{C}_{0}=\mathrm{TN} \times 6.38, \mathrm{OC}_{25}$ and $\mathrm{BC}_{25}=\mathrm{TN} \times 6.2425, \mathrm{BC}_{50}=\mathrm{TN} \times 6.105, \mathrm{OBC}_{75}=$

TN x 5.968

A, B, C, D, E Means with same letter in each column are not significantly different. SE \pm

\subsubsection{Nutritional label}

Table (9) gave a good example of nutritional label of ice milk. The results presented in this table showed that $\mathrm{BC}_{25^{-}}, \mathrm{BC}_{50^{-}}, \mathrm{OC}_{25^{-}}$and $\mathrm{OBC}_{75^{-}}$ice milk provides vital constituents and nutrients of milk and cereal, such as calories, fat, protein, carbohydrate and dietary fibers. $\mathrm{BC}_{25}$ - ice milk was the nearer nutritionally to $\mathrm{C}_{0}$ then $\mathrm{BC}_{50^{-}}$and $\mathrm{OC}_{25^{-}}$ice milk.

Consequently, it could be concluded that, grain barley components (up to 50\%) and grain oat components (up to $25 \%$ ) could be used as non fat milk solids substitutes in the manufacture of like ice milk with high quality and cheap. 
The use of cereal components in the preparation of ice milk

Table 9. Nutritive value of one serving $(120 \mathrm{ml})$ of most acceptable ice milks.

\begin{tabular}{|l|rrrrr|}
\hline \multirow{2}{*}{ Constituents } & \multicolumn{4}{|c|}{ Ice milks $^{\mathbf{1}}$} \\
\cline { 2 - 6 } & $\mathbf{C}_{\mathbf{0}}$ & $\mathbf{O C}_{\mathbf{2 5}}$ & $\mathbf{B C}_{\mathbf{2 5}}$ & $\mathbf{B C}_{\mathbf{5 0}}$ & $\mathbf{O B C}_{\mathbf{7 5}}$ \\
\hline Total calories, Kcal & 107.91 & 110.21 & 115.41 & 136.55 & 126.38 \\
\% Daily Value & $\mathbf{2}$ & 5.51 & 5.77 & 6.83 & 6.32 \\
\hline Fat, g & 5.40 & 3.21 & 3.37 & 4.15 & 3.74 \\
\% Daily Value & 3.23 & 5.07 & 5.32 & 6.55 & 5.91 \\
\hline Protein, g & 5.10 & 3.20 & 3.28 & 3.04 & 2.16 \\
\% Daily Value & 3.68 & 6.40 & 6.56 & 6.08 & 4.32 \\
\hline Total carbohydrates, g & 7.36 & 17.13 & 17.99 & 21.76 & 21.02 \\
\% Daily Value & 16.03 & 5.27 & 5.54 & 6.70 & 6.47 \\
Carbohydrate, g & 4.93 & 16.84 & 17.76 & 21.40 & 20.58 \\
Dietary fibers, g & 16.03 & 0.29 & 0.23 & 0.36 & 0.44 \\
\% Recommended Daily Intake & 0.00 & 1.16 & 0.92 & 1.44 & 1.76 \\
\hline
\end{tabular}

1 see Table 1

$2 \%$ Daily value is based on 2000 calorie diet (www.nal.usda.gov/fnci/foodcomp)

${ }^{3}$ FDA (1997) (http://vm.cfsan.fda.gov/_Ird/fr970123.html)

\section{References}

[1] A.O.A.C. (1990). Official Methods of Analysis. $15^{\text {th }}$ Ed. Association of Official Analytical Chemists, Inc., USA.

[2] Ahanian, B., Rezvan, P. and Fardin, M. (2014). Effect of substitut- ing soy milk instead of skim milk on physicochemical and sensory properties of sesame ice cream. Indian Journal Science \& Research, 7(1): $1134-1143$.

[3] Ali, M. S. A. (2012). Studies on some dairy products substitutes. M.Sc. Thesis, Faculty of Agric., Cairo University, Egypt.

[4] Arbuckle, W.S. (1986). Ice Cream. $4^{\text {th }}$ Ed., AVI Pub. Co., Inc. Westport, Connecticut, USA.

[5] Azzam, M.A. (2003). Production of low-calorie ice milk. J. Agric.Sci. Mansoura Univ., 28 (12): 8139 - 8150.

[6] Bisla, G., Archana, Verma, P. and Sharma, S. (2012).Development of ice creams from soybean milk and watermelon seeds milkand evaluation of their acceptability and nourishing potential. Advances in Applied Science Research, 3(1):371 - 376.

[7] Bolliger, S., Goff, H.D., Tharp, B.W. (2000): Correlation between colloidal properties of ice cream mix and ice cream. International Dairy Journal, 10: $303-309$.

[8] Buck, J. S., Walker, C. E. and Pierce, M. M. (1986). Evaluation of sucrose esters in ice cream. Journal of Food Science. 51:489.

[9] Burake, A.K. (1947). Practical ice cream making. Olsen Publishing Co., Wilwauke, WI., USA

[10] Das, T. C., Rao, M. R., Reddy, C. R., Krishnaiah, N. and Sudhakar, K. (1989). Ice-cream Made by incorporation of different levels of Potato pulp. Indian Journal of Dairy Science, 42: 295 - 297.

[11] Egyptian standards 1185-1 (2005). Egyptian Organization for Sta-ndardization and Quality, ARE.

[12] El-Samahy, S.K.; Gaballah, A.A.; Embaby, H.E.; Hamed, Y.S. and Khalil, R.A.M. (2015). Producing novel low fat ice creamusing substantial amounts of Cactus fruit (opuntia dillenii) pulp. Egyptian J. Dairy Sci., 43: 91 - 104.

[13] Erkaya, T.; Dağdemir, E. and Şengül, M. (2011). Influence of cape gooseberry (physalis peruviana L.) addition on the chemicaland sensory characteristics and mineral concentrations of ice cream. Food Research International, 45(1): 331-335.

[14] Farahat, A.M., El-Batawy, O.I. and Gadalla, E.G. (2011). Preparati-on of functional ice cream fortified with date pulp. Egyptian J. Dairy Sci., 39: $285-291$.

[15] FDA (Food and Drug Administration) (1997). http://vm.cfsan.fda.go v/_Ird/fr970123.html (accessed 5 May 2002).

[16] Hurrell, RF, Reddy, MB., Burri, J., Cook, JD. (2000). An evaluation of EDTA compounds for iron fortification of cereal based foods. British Journal Nutrition, 84(6):903 - 910.

[17] Hüttner, E.K., Arendt, E.K. (2010). Recent advances in gluten-free baking and the current status of oats. Trends in FoodScience \& Technology, 21(6):303 - 312.

[18] Hwang, J. Y., Shyu, Y. S., and Hsu, C. K. (2009). Grape wine lees improves the rheological and adds antioxidant properties to ice cream. Lebensmittel-Wissenschaft \& Technology, 42:312 -318.

[19] Karaman, S., and Ahmed K. (2012). Rheology of ice cream mix flavored with Black Tea or Herbal Teas and effect of flavoring on the sensory properties of ice cream. Food \& Bioprocess Technology, 5(8): $3159-3169$.

[20] Marshall, R.T. and Arbuckle, W.S. (1996). Ice cream. $5^{\text {th }}$ Ed. Chapman and Hall, New York, USA.

[21] Marshall, R.T.; Goff, H.D. and Hartel, W.R. (2003). Ice cream. $6^{\text {th }}$ Ed. Kluwer Academic/Plenum Pub., New York, USA

[22] Mohan, BH., Gopal, A., Malleshi, NG, Tharanathan, RN. (2005). Characteristics of native and enzymatically hydrolyzed ragi (Eleusine coracana) and rice (Oryza sativa) starches. Carbohydrate Polymers, 59:43 - 50.

[23] Newman, C.W., Newman, R.K., (2006). A brief history of barley foods. Cereal Foods World, 51, 4-7.

[24] Patel, I. J., Dharaiya, C. N. and Pinto, S. V. (2015). Development of technology for manufacture of ragi ice cream. Journal of Food Science \& Technology, 52(7):4015 - 4028 .

[25] Person, D. (1976). The chemical analysis of foods. $7^{\text {th }}$ Ed., published by Churchill Livingstone, Edinburgh London and New York, pp. $496-497$.

[26] Queenan, K.M., Stewart, M.L., Smith, K.N., Thomas W., Fulcher, R.G. and Slavin, J.L. (2007). Concentrated oat $\beta$-glucan, a fermentable fiber, lowers serum cholesterol in hypercholesterolemic adults in a randomized controlled trial. Nutritional Journal, 6(6): $1-8$.

[27] Rosalina, P., Sofjan, RP, Hartel, RW. (2004). Effects of overrun on structural and physical characteristics of ice cream. International of Dairy Journal, 14(3):255 - 262.

[28] Salama, F.M.M. (2004). The use of some natural sweeteners in ice cream manufacture. Egyptian J.Dairy Sci., $32: 355$ - 366.

[29] Soukoulis, C., Lebesi, D. and Tzia, C. (2009). Enrichment of ice cream with dietary fiber: Effects on rheological properties, ice crystallisation and glass transition phenomena. Food Chemistry, 115(2): $665-671$.

[30] Stanley, D. W., Goff, H. D. and Smith, A. K. (1996). Texture-structure relationships in foamed dairy emulsions. Food Research International, 29:1-13.

[31] Steel, R.G.D., Torrie, J.H. and Dickey, D. (1997). Principles and Procedures of Statistics: A Biometrical Approach. $3^{\text {rd }}$ Ed. McGraw Hill Book Co. New York, USA.

[32] Sun-Waterhouse, D., Edmonds, L., Wadhwa, S. S. and Wibisono, R. (2013). Producing ice cream using a substantial amount of juice from Kiwifruit with green, gold or red flesh. Food Research International, 50(2): 647-656. 
[33] Umelo, M.C., Uzoukwu, A. E. and Odimegwu, E N. (2014). Proximate, physicochemical and sensory evaluation of ice cream from blends of cow milk and tigernut (Cyperus Esculentus ) milk. International Journal of Scientific Research \& Innovative Technology,1(4): $63-76$.

[34] Walsh, H., Ross, J., Hendricks, G. and Guo, M. (2010). Physico- chemical properties, probiotic survivability, microstructure and acceptability of a yogurt-like symbiotic oats-based product using pre-polymerized whey protein as a gelation agent. Journal of Food Science, 75(5): 327-337.

[35] Wangcharoen, Wiwat. (2012). "Development of Ginger- flavoured Soya milk ice cream: Comparison of data analysis methods." Maejo International Journal of Science \& Technology 6(3): $505-513$.

[36] Winton, A. L. (1958). Analysis of Foods. $3^{\text {rd }}$ Ed. John Wiley and Sons Inc., New York, USA. 